Article

\title{
Study of STEM for Sustainability in Design Education: Framework for Student Learning and Outcomes with Design for a Disaster Project
}

\author{
Ming-Ni Chan ${ }^{1}$ and Daisuke Nagatomo ${ }^{2, *(D)}$ \\ 1 PhD Program in Design, College of Design, Chung Yuan Christian University, Taoyuan City 320, Taiwan; \\ minniejan@gmail.com \\ 2 Department of Design, National Taiwan Normal University, Taipei City 106, Taiwan \\ * Correspondence: dn@ntnu.edu.tw; Tel.: +886-978-081580
}

check for

updates

Citation: Chan, M.-N.; Nagatomo, D. Study of STEM for Sustainability in Design Education: Framework for Student Learning and Outcomes with Design for a Disaster Project.

Sustainability 2022, 14, 312. https:// doi.org/10.3390/su14010312

Academic Editors: Knut Neumann, Troy D. Sadler, Chun-Yen Chang and Jing Lin

Received: 29 November 2021

Accepted: 24 December 2021

Published: 28 December 2021

Publisher's Note: MDPI stays neutral with regard to jurisdictional claims in published maps and institutional affiliations.

Copyright: (c) 2021 by the authors Licensee MDPI, Basel, Switzerland. This article is an open access article distributed under the terms and conditions of the Creative Commons Attribution (CC BY) license (https:// creativecommons.org/licenses/by/ $4.0 /)$.

\begin{abstract}
STEM has successfully introduced an interdisciplinary education model that can be used for training students to develop skillsets for the 21st century. STEM Education for Sustainability (STEM4S) expands the scope of education to meet rapidly changing global challenges, such as climate change and SDGs by the United Nations, which require the multidisciplinary curriculum to be integrated into STEM. Design-based tasks play a significant role in STEM education by promoting students' critical thinking and problem-solving abilities. While STEM successfully employs design, design education currently conducts subjective procedures and lacks the framework for adopting the critical-thinking process. Therefore, design education can develop students' cognitive skills by reflecting on STEM learning experiences. This study articulates the framework for design education by investigating problem-based and project-based learning and the double-diamond diagram for innovation. The goal of this study was to apply these observations and formulate the framework for STEM4S. This study examined the framework adopted at the National Taiwan Normal University in the Department of Design, with qualitative analysis of participants and quantitative analysis of questionnaire results. Finally, the researchers discuss the research questions and future applications of this framework.
\end{abstract}

Keywords: PBL; STEM4S; critical thinking; design education

\section{Introduction}

The STEM education movement initially gained attention at the beginning of the 1990s in the United States and expanded internationally. Based on past STEM research, STEM brings cognitive, procedural, and attitudinal benefits to students [1]. STEM encourages students to develop solutions to problems with the knowledge and skills of science, technology, engineering, and mathematics [2]. Although the definition of STEM education is broad and open to various interpretations, the term "interdisciplinary" is one of the commonly used ways to describe the theoretical and instructional approach to STEM education [3]. STEM education also shows much potential in helping students develop literacy that will be required as 21st-century citizens and professionals [4].

Since the United Nations initiated the Sustainable Development Goals (SDGs) in 2015 [5], the roles of higher education institutions need clarification for adapting the necessary changes [6]. Defining how to include the SDGs into higher education is still in an early stage [7], thus requiring evaluation of different disciplinary education and methods [8]. The concept of STEM Education for Sustainability (STEM4S) expands the STEM interdisciplinary education scope for problem-solving to a multidisciplinary critical-thinking method and sustainability mindsets [9]. Multidisciplinary curricula create challenges for students to see sustainability as outside the normal realm of their discipline and provide educators 
with the opportunity to address the gaps between interdisciplinary STEM-based education and STEM4S [10].

The Taiwanese Ministry of Education developed the Curriculum Guidelines of 12-Year Basic Education-Science (CGBE-S) to reform the curriculum to employ STEM in 2018 [11]. Due to the regional reasons of limited natural resources, advanced science and technology could bring a higher chance of competitive economic advantages. Taiwanese higher education has helped students to obtain STEM-related abilities by employing independent learning and exploring new learning areas and methods [12]. Although many Taiwanese institutes have adapted the Education for Sustainable Development (ESD) strategies, such as the Sustainable Campus Program and Green School Partnership Project, the researchers posit that it is difficult to evaluate the outcome of ESD strategies [13]. The researchers of Green schools in Taiwan mentioned that the bureaucratic execution model in Taiwan has limited the actual implementation of ESD in the social system for addressing the country's environmental problems. Moreover, learners should have more opportunities to cultivate their critical reflection on political and physical real-world challenges [14].

The inclusion of sustainability in higher education is the essential component in SDG4 (Quality Education), which defines educational policy and practice at all levels through teaching and research. Higher education is expected to deliver knowledge and innovation to meet societal, economic, and environmental challenges through academic staff and students [15]. Even though the United Nations Educational, Scientific, and Cultural Organization (UNESCO) recommends teaching STEM-related subjects in the 21st century for sustainable development, STEM at the university level receives minimal attention. Due to the complexity of the STEM education system, the activities are conducted through project-based, inquiry-based, and problem-based learning. However, these activities require frameworks, which challenge instructors in preparing materials [8]. Design-based tasks play a significant role in STEM education by encouraging students' critical thinking and problem-solving abilities [16]. While STEM successfully employs design, design education currently involves subjective procedures and lacks the framework for adopting the critical-thinking process [17]. Therefore, design education has the opportunity to develop students' cognitive skills by reflecting on STEM learning experiences. This study articulates the framework for design education by investigating problem-based and project-based learning and the double-diamond diagram for innovation.

\section{Design as an Education Method}

The common themes in design definitions include creating something new, humancentered design, and focusing on problem framing over solution development [18]. Incorporating design-based tasks could allow students to explore their creativity [19]. Based on the research by Fortus et al., design can be a vehicle for scientific knowledge and real-world problem-solving skills [20]. In their research, "Design-based science and student learning", they distinguish between design as an everyday activity and Design (capital D) as an activity in which professional designers engage. The researchers explored design-based science (DBS) for supporting students to construct scientific knowledge and problem-solving skills. The goal of DBS implementation was not to instruct the students about design but to engage students in learning science. The research indicates that the result of DBS units shows substantial scientific knowledge for solving design problems. Design-based teaching methods can be a problem for teachers in terms of expected outcomes of students, since they deals with "how" questions rather than "why" or "what". Teachers of DBS need to answer these "how" questions. Therefore, it is not easy to foresee the results of students or prepare classes.

Li et al. (2019) pointed out that design thinking is essential for every student to develop and have in the 21st century [16]. STEM education can provide diverse opportunities to facilitate students' learning through design and can enhance their design thinking. This research suggests that implementing design in educational activities and the curriculum could amplify students' problem-solving skills by promoting their design thinking. While 
design thinking often refers to innovation and creativity by solving problems, actual application methods utilize either problem- or project-based learning in STEM [21]. However, problem- and project-based learning could affect students' problem-solving ability development, and literacy could be different. Thus, we first examined students' problem-solving ability development by comparing problem- and project-based learning.

\section{Project- and Problem-Based Learning}

Project-/problem-based learning is currently one of the most common learning experiences in STEM education. However, we use PBL as a broad term, encompassing many approaches (including both problem- and project-based learning) [21]. Problem-based learning is an instructional learner-centered approach to train learners to obtain skills and knowledge to develop a viable solution to a defined problem [22]. Project-based learning is a comprehensive approach to teaching and learning to engage learners with projects that motivate them to investigate solutions [23]. In STEM education, PBL is defined as the term for a set of instructional strategies for learners to conduct research, integrate theory and practice, and apply knowledge. There are a few types of PBL. However, the most common PBL application is problem-solving projects, where students complete a series of discrete tasks and form a product rooted in a problem to be solved [21].

While problem- and project-based learning carry many similarities, there are a few unique characteristics of each learning experience (Table 1). Problem-based learning could promote more interdisciplinary investigation for problem-solving, while project-based learning could provide more opportunities to acquire professional knowledge by working on projects. However, there are a few difficulties with each learning experience. Problembased learning requires sufficient investment in developing problems in the class, while project-based learning requires the professional knowledge of teachers and preparing projects to keep students motivated [22,23]. These difficulties show how PBL needs sufficient preparation before class, and teachers who conduct PBL classes need professional and educational training.

Table 1. Comparison of problem- and project-based learning.

\begin{tabular}{|c|c|c|}
\hline & Problem-Based Learning & Project-Based Learning \\
\hline Objective & $\begin{array}{l}\text { Trains students to obtain skills and } \\
\text { knowledge to develop solutions. }\end{array}$ & $\begin{array}{l}\text { Engages students with projects for } \\
\text { investigating solutions. }\end{array}$ \\
\hline Strength & $\begin{array}{l}\text { Promotes students' interdisciplinary } \\
\text { investigation to solve problems. }\end{array}$ & $\begin{array}{l}\text { Provides students opportunities to } \\
\text { acquire professional knowledge. }\end{array}$ \\
\hline Difficulty & $\begin{array}{c}\text { Requires sufficient investment in } \\
\text { developing problems. }\end{array}$ & $\begin{array}{l}\text { Requires professional knowledge of } \\
\text { teachers and well-prepared projects. }\end{array}$ \\
\hline
\end{tabular}

\section{Design Education and STEM}

\subsection{Studio System in Design Education}

"Design and design thinking is vital to creativity and innovation and have become increasingly important in the current movement of developing and implementing integrated STEM education [16]". While design thinking promotes learners to ideate the problem and create innovative solutions through testing and prototyping, design education seems to balance its weight more on the esthetics and utility of items in our daily lives [24]. Typically, designers use design-thinking steps in their design process to solve problems for producing their design outcomes, and they use their esthetics to evaluate these solutions [25]. Therefore, most design educators employ a studio system where students establish apprentice relationships with their teachers to learn design skills. The studio working pattern often incorporates the open-ended problem and is revisited repeatedly in a generative process [26]. Through the studio system, students learn not by assimilation but by trial-and-error practice, and they make themselves into reflective practitioners and develop their projects [27]. However, some researchers have pointed out the issues with the studio system [27-29]. A summary is as follows: 
- The design studio system tends to be subjective in both instruction and learning;

- The design studio system often fails to provide effective design-thinking education;

- $\quad$ Requisite design teaching knowledge is difficult to define, thus leading to insufficient instructions of the design process and inefficiencies in learning.

These issues indicate that the studio system is not easily used to establish an objective evaluation system, a step-by-step teaching method and learning process, and an evaluation method of student's learning accomplishment. Once we superimpose the STEM designthinking method over the studio-teaching method, these issues are identifiable. While design thinking employs an infinite loop of critical thinking and problem-solving, the studio assignments are ambiguous in terms of the targeted problem, evaluation method, and the implementation of the testing and prototyping phase. While instructors and students need to seek solutions via subjective observation of the design subjects, criteria are lacking, resulting in social issues and innovation. These are reasons why the STEM education method could elevate design education: by implementing the correct PBL learning experience.

\subsection{Project-Based Learning in the Studio System}

When we superimpose the project-based learning criteria over the design-studio process, there are four phases in students' project development (Figure 1). We named these phases acquirement, articulation, challenge, and solution. In the acquirement phase, students need to understand the project requirement, expectations, and challenges [30]. Students typically start collecting references and conduct case studies in this phase. They then try to implement their interests into their projects in the articulation phase by addressing a problem and generating potential design strategies. Instructors require professional knowledge and an esthetic sense to evaluate students' projects in this phase. In the challenge phase, students try to balance their problem and the project requirements. Typically, students have some choice of self-direction within the scope of the process [26]. Each student develops his or her problems in his or her project, so the instructor needs to put forth a lot more effort to guide students to find solutions. Finally, in the solution phase, the students create solutions to the project and problem with their technical and esthetic skills and present them to the reviewers. The quality of the presentation varies by each student's ability, as well as the instructor's clear guidance. Therefore, it is not easy to evaluate the development of a student's problem-solving ability without clear guidelines.

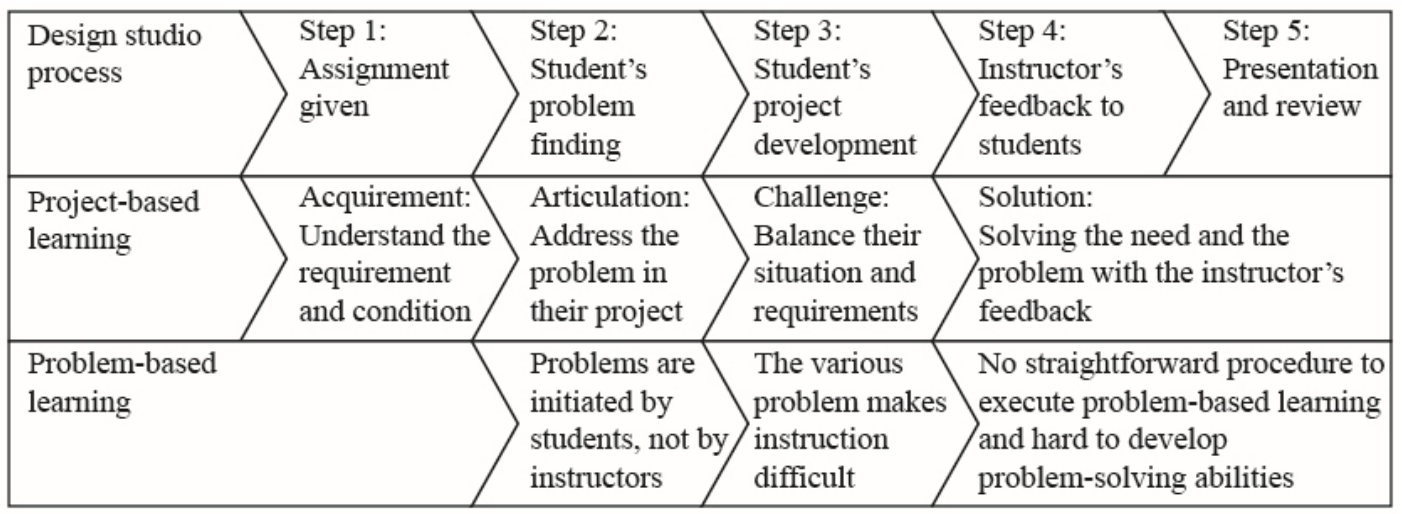

Figure 1. Procedure of the design studio and comparison of superimposing project-based learning criteria and problem-based learning issues.

\subsection{Application of a Framework in Design Education}

The above paragraph mentioned that design education often lacks a clear framework and design-thinking procedure. Research conducted by Oxman (2003) indicated that most design schools rarely, if ever, treat the cognitive processes of design thinking as a form of explicit teaching content [17]. However, design thinking reflects the complex process of 
inquiry and learning, which involves performing in a systematic context, decision-making, and collaborative working [31]. Figure 2 describes the state of the design-thinking stage while students are conducting a design studio with project-based learning (Figure 2). It explains that students need to keep going back and forth in the design-thinking stages in most phases. These factors also make teaching design difficult. Thus, we created a hypothesis of applying a clear framework for students to work on a design project and measure the effectiveness.

\section{Project-Based Learning in Studio System}

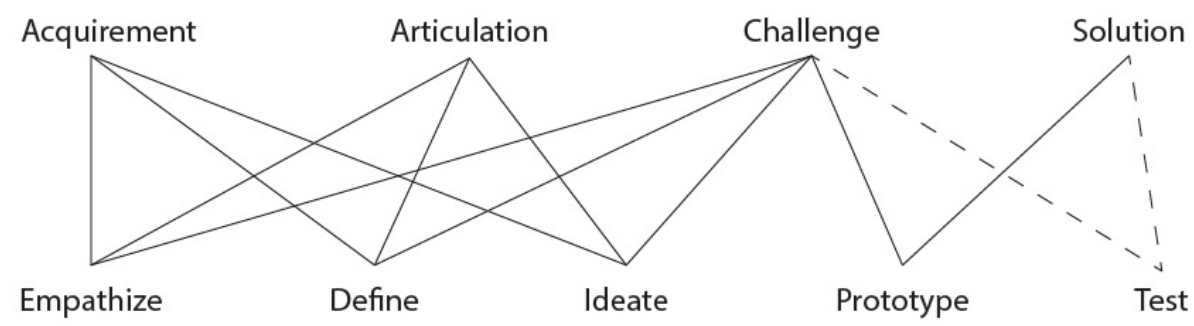

\section{Design thinking process}

Figure 2. Project-based learning in studio and design-thinking process (illustrated by the authors).

Kremer et al. (2006) mentioned that the guidelines for design pedagogic tasks need to include the following [32]:

- Authentic hands-on tasks;

- Familiar and easy-to-use material;

- Clearly defined outcomes;

- Collaborative work and higher-order thinking;

- Multiple design iterations;

- Clear links to a limited number of science and engineering concepts.

Chiaradia et al. (2017) pointed out that the iterative cycle of belief and action in the design process is ubiquitous in the literature, and all design process models involve evaluation. The ability to extend design intention to evaluation frames distinguishes the novice from the expert designer [30]. To achieve these pedagogic tasks and achieve evaluation in the process, we looked into the procedural framework that implements design-thinking feedback loops.

Banathy (2003) stated that design manifests dynamic interaction between feedback and feedforward, refection and creation, and divergence and convergence. The dynamics of divergence and convergence form a double-diamond relationship in the design process [33]. The UK Design Council later applied this double diamond to define the Framework for Innovation (Figure 3), which consists of four steps: discover, define, develop, and deliver. The first diamond includes discover and define. The discovery phase is for people to understand what the problem is, rather than assume what it is. After gathering insight during the discovery phase, people need to define the challenge. The second diamond consists of develop and deliver. The developing phase engages people to provide different answers to the clearly defined problem, while the delivery phase involves testing out solutions and evaluating outcomes to create innovative solutions [34]. The diagram is not necessarily shown as a linear process but can bring the process back to the beginning to identify underlying problems.

This framework intends to present a clear challenge in students' assignments and create a guideline for their project development. The project assignment needs to consider the student's knowledge and skill level for the degree of the challenge, and students have some tools to develop under the instructor's guidance. It is also necessary to plan a clear expectation for student outcomes, and the instructor needs to promote students' creativity to avoid design fixation in their development process. We employed this double-diamond 
diagram to synchronize the STEM design-thinking process to conduct students' design projects. Therefore, we named this framework the STEM Double-Diamond Innovation Framework (STEM DDIF). STEM DDIF promotes design thinking in project-based learning, which particularly requires critical thinking and problem-solving ability. Therefore, we expect that STEM DDIF can perform well in studio-system design education.

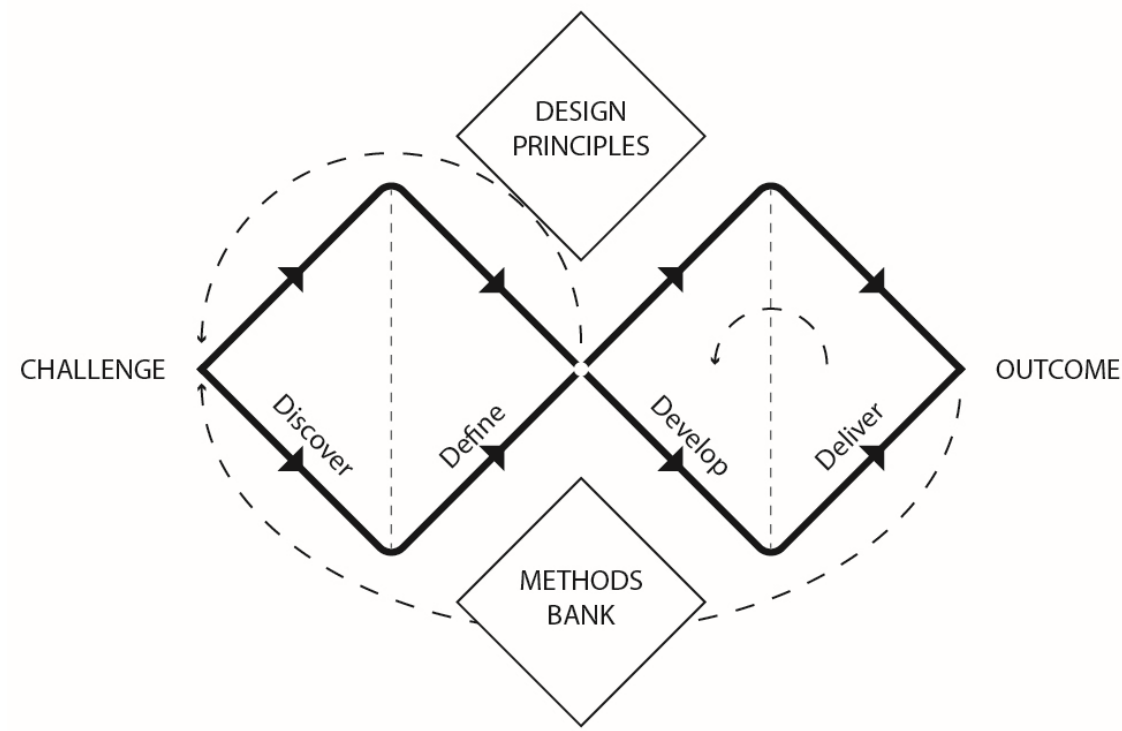

Figure 3. Base of STEM DDIF employing the Framework for Innovation from the UK Design Council (re-illustrated by the authors).

\section{Method}

In this investigation, we explored design education with the following focuses:

(1) Applying STEM4S scope;

(2) Conducting design studio with STEM DDIF;

(3) Measuring the outcome of students' critical thinking development.

\subsection{Observation of Participants}

To apply the STEM4S scope, the class needed to follow a multidisciplinary approach. We incorporated this into the course guide of Innovation Design (I) of the Department of Design, National Taiwan Normal University (NTNU). Innovation Design (I) is the designstudio base and mandatory class for product-design students. The class totaled 20 students (18 students from the Department of Design, one student from the Department of Learning Science, and one student from the Department of Geography). The student from the Department of Geography enrolled in the Department of Design as a double-major. The students completed their first-year courses, including basic design and model-making, as their prerequisite to enroll in this class. However, their design skills in computer software and professional knowledge were still developing. NTNU's product-design course has traditionally focused on form, function, and esthetic education. While the Department of Design belongs to the College of Arts and shares the substantial core value of art education with the Fine Art Department, there is no specific course to teach sustainable design or SDG-related subjects. In terms of ranking standing, NTNU is considered the best Normal University in Taiwan, and students go through an arduous evaluation process to receive admission to the school. In general, the school tests students' cognitive skills in remembering and understanding. However, students are relatively conservative and afraid of making mistakes. For these reasons, Innovation Design (I) was a novel challenge.

Since our goal was to adopt the STEM4S scope, we introduced a guest lecture and consulting session for students, besides the typical design studio system, such as desk critic and final presentation, to gain a multidisciplinary approach. Table 2 shows the guest 
lecturer, consultant, and jury members (Table 2). These instructors were selected due to their experiences in sustainability-related projects and a solid understanding of this project's students' challenges. The guest lecturer acted as the inspiration and motivation for students to carry out the course tasks. While the consultant session provided students with a sense of working with professionals and motivation, the gust juries provided feedback on their outcomes. The combination of these guest instructors worked well, since they were already familiar with each other and reflected each other's opinions during the jury sessions.

Table 2. Participants' (instructor side) background.

\begin{tabular}{|c|c|c|}
\hline Roles & Discipline & Note \\
\hline $\begin{array}{c}\text { Guest Lecturer/Jury } \\
\text { (Co-Research Investigator) }\end{array}$ & Interior Design & $\begin{array}{l}\text { Architecture background Interior } \\
\text { Designer who has experience in } \\
\text { designing cardboard projects. } \\
\text { Structural engineering expert and }\end{array}$ \\
\hline Consultant & Structural Engineering & $\begin{array}{c}\text { Adjunct Associate Professor at National } \\
\text { Taiwan University. }\end{array}$ \\
\hline Jury 1 (1st Project) & Industrial Design & $\begin{array}{c}\text { Industrial design background full-time } \\
\text { Associate Professor at NTNU. } \\
\text { Architecture background full-time }\end{array}$ \\
\hline Jury 2 (2nd Project) & Architecture & $\begin{array}{c}\text { Professor at National Yang Ming Chao } \\
\text { Tung University. }\end{array}$ \\
\hline
\end{tabular}

\subsection{Course Objective}

The objective of the class needed to address the concern for sustainability, which can push students to think outside of their norm. Thus, we chose the class topic to be Design for Disaster. The requirement for students was to design an interior shelter and furniture with corrugated cardboard. Taiwanese geographic conditions with typhoons, torrential rain, and earthquakes often cause natural disasters. Taiwanese mass media often broadcast these scenes. The assignment intended to raise the awareness of the social issues more objectively than subjectively, allowing students to develop a more people-centered design. The first phase involved designing indoor cardboard furniture for disaster relief. In this phase, the students learned how to adopt cardboard material and researched the needs of disaster relief. The second phase was to build a full-scale indoor shelter with group members. The second phase required more design-thinking processes and collaboration with team members. The students explored design possibilities by prototyping small-scale mock-up and learning from issues.

\subsection{The First Half of the Double Diamond}

The first half of the STEM DDIF is to envision the problems to solve in the project. It is an essential part of the problem-based learning experience. In the typical designstudio format, these envisioning phases blur the approach of the problem-solving process. Since the students' design knowledge level was still in a developing state, we allowed the students to explore the issues and guided them within limits. The constraints we gave the students were as follows:

- The site is for indoor disaster relief;

- The design needs easy assembly for the user;

- $\quad$ The material choice and size.

After we provided these prerequisites and conditions for the project development, we invited the guest lecturer to share personal working experiences with a similar design project. The guest lecturer, the co-investigator of this project, introduced the students to the design-thinking process of project development. The purpose of this lecture was to show how professionals conduct actual projects and to inspire the students' creativity. 


\subsection{Material}

As the medium for developing projects, we selected corrugated cardboard. The strength of this material is flexible and easy to edit without professional knowledge. It comes in standardized dimensions, with different thicknesses, such as 1, 3, 5, and $8 \mathrm{~mm}$. These different thicknesses help students think with smaller and larger prototypes and quickly test their ideas. Students used $1 \mathrm{~mm}$ cardboard to make 1:5 scale models, as well as $5 \mathrm{~mm}$-thick cardboard to complete full-scale furniture prototypes for the first assignment (Figure 4). Afterward, students used $3 \mathrm{~mm}$-thick cardboard to build 1:10 scale models, as well as the $8 \mathrm{~mm}$-thick cardboard to construct the final full-scale shelter (Figure 5). We also informed the students that there is a well-developed paper-recycling system in Taiwan. Most of the cardboard waste can be recycled into other paper products [35]. We encouraged our students to think not just about the design of the product but also about the lifespan and the end of the product's life.

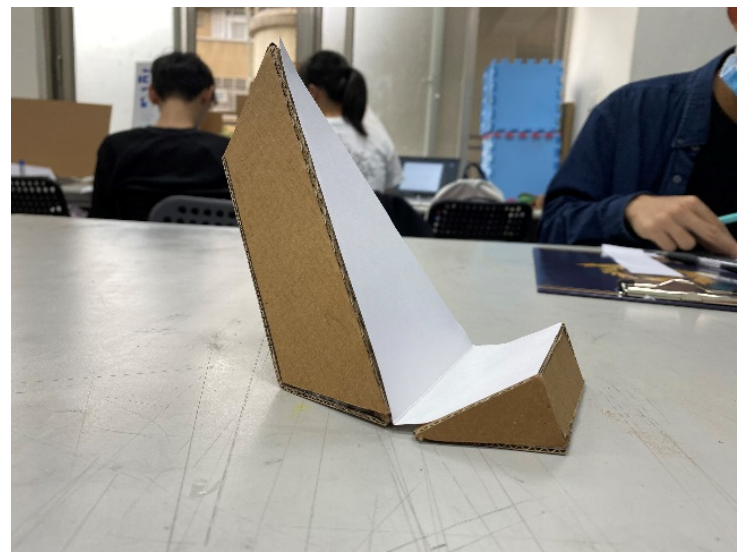

(a)

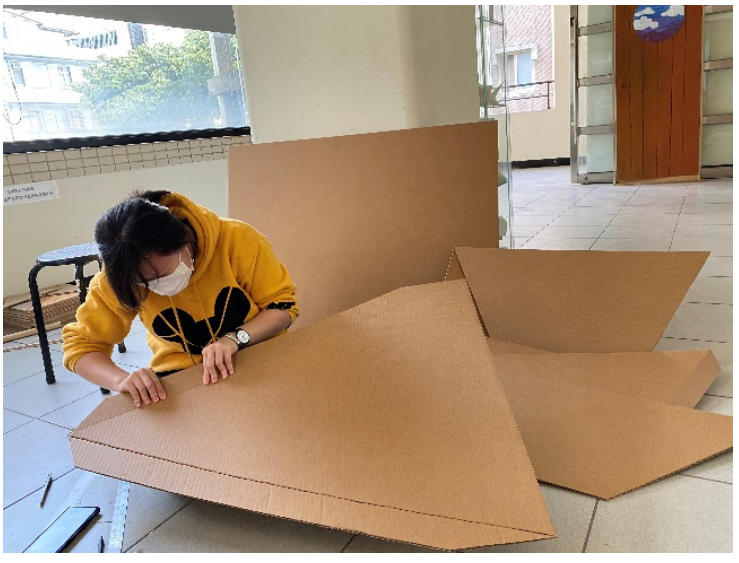

(b)

Figure 4. (a) A 1:5 scale model with $1 \mathrm{~mm}$-thick cardboard. (b) Full-scale furniture prototype with 5 mm-thick cardboard.

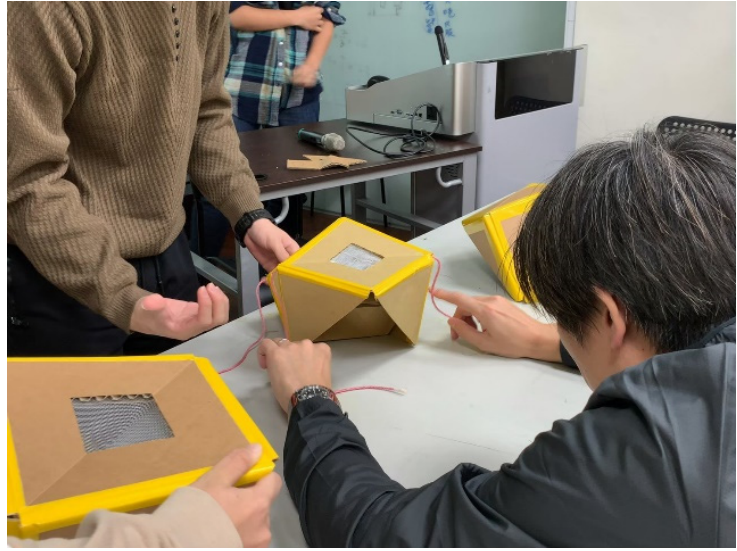

(a)

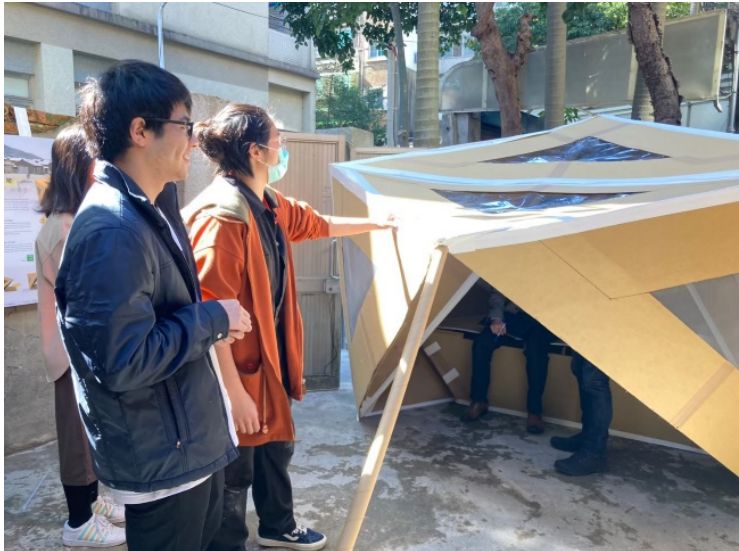

(b)

Figure 5. (a) A 1:10 scale model with 3 mm-thick cardboard. (b) Full-scale shelter prototype with $8 \mathrm{~mm}$-thick cardboard.

\subsection{Evaluation}

We set up three review sessions: the first-phase final review, the structural engineer's consulting sessions, and the second-phase final review for students to interact with reviewers. The first-phase reviewers were the course instructor, the guest lecturer, and a 
professor from NTNU's Department of Design. In this session, the students presented their cardboard furniture designs for disaster relief. After the first phase had concluded, we divided the students into groups for the second phase, in which they discussed their ideas and achievements from the first phase and started their brainstorming session. Since most students faced difficulty thinking of large-scale shelter designs, we invited the professional structural engineer for a consulting session. The students explained their 1:10 scale models and discussed a solution for the problem with the engineer. The final phase of the project involved building a full-scale prototype of a disaster-relief shelter. There were a total of five groups to develop full-scale prototypes. They presented their design solutions for disaster projects before final juries with their prototypes. In Figure 6, we describe how we implemented the STEM DDIF in this class.

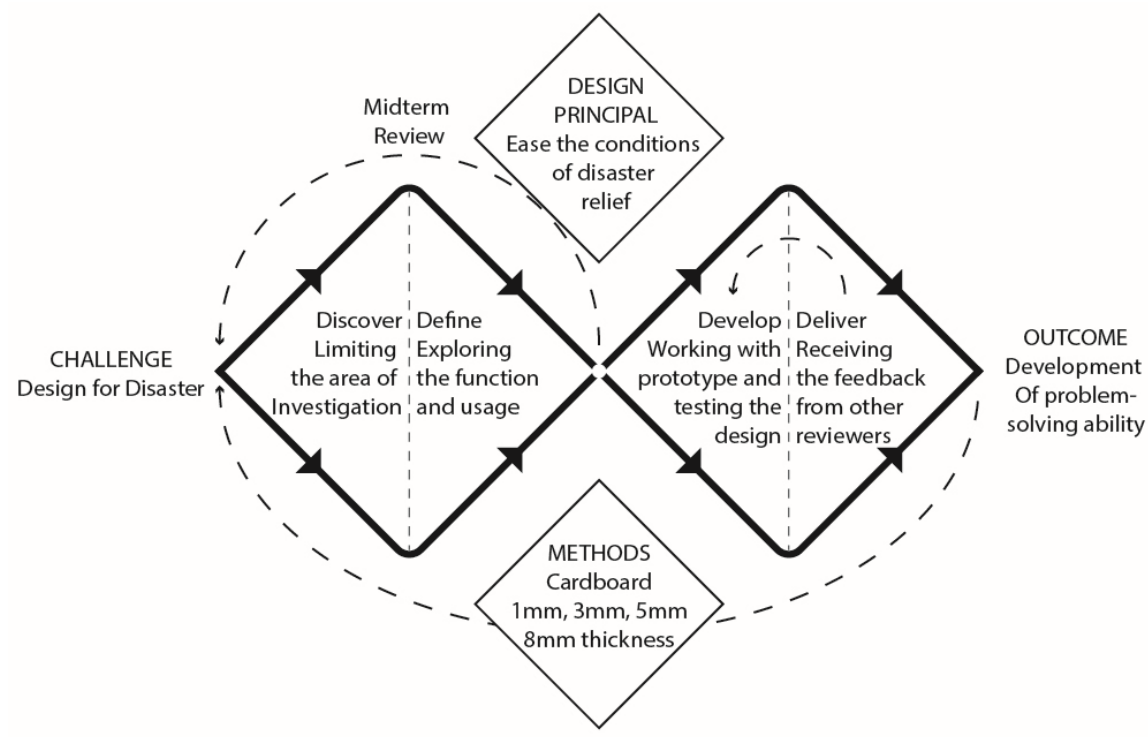

Figure 6. Adapted STEM DDIF for Innovation Design (I).

To evaluate the outcome of the students' critical-thinking development, we asked them to respond to the questionnaire after they completed all of the tasks. The contents of the questionnaire were as follows:

- Students' awareness of problem-based learning;

- The course's contributions to their learning;

- Impression of the problem-based learning method;

- Opinion about the course content.

In the section about the course's contributions to their learning, we asked the students to self-evaluate their skill level before and after the class. The impression of the problembased learning section involved understanding how this learning experience promotes them to work as a group and to face the challenge to solve the problems. We also let the students express their opinion by commenting on the valuable aspect of this course and any feedback to improve the class content. The questionnaire is provided in Table 3. After analyzing their feedback, we evaluated the effectiveness of the framework and the development of students' critical thinking. 
Table 3. End-of-semester questionnaire.

\begin{tabular}{|c|c|c|c|}
\hline Question Type & Question No. & Question Content & Answer Type \\
\hline \multirow{4}{*}{ Skill-Level Self-Evaluation } & Q1 & Level of skill/knowledge at start of course & Satisfactory \\
\hline & Q2 & Level of skill/knowledge at end of course & Satisfactory \\
\hline & Q3 & Level of skill/knowledge required to complete the course & Satisfactory \\
\hline & Q4 & Contribution of the course to your skill/knowledge & Satisfactory \\
\hline \multirow{6}{*}{ Problem-Based Learning } & Q5 & The assignment level was too difficult to work with & Agreement \\
\hline & Q6 & This course has sharpened my critical thinking & Agreement \\
\hline & Q7 & $\begin{array}{l}\text { As a result of my course, I feel confident about } \\
\text { facing challenges }\end{array}$ & Agreement \\
\hline & Q8 & $\begin{array}{l}\text { This course has helped develop my ability to work as a } \\
\text { team member }\end{array}$ & Agreement \\
\hline & Q9 & This course has improved my communication skills & Agreement \\
\hline & Q10 & Overall, I am satisfied with the quality of my work & Agreement \\
\hline \multirow{4}{*}{ Course Content } & Q11 & The learning objectives were clear & Agreement \\
\hline & Q12 & The course content was organized and well-planned & Agreement \\
\hline & Q13 & The course workload was appropriate & Agreement \\
\hline & Q14 & $\begin{array}{l}\text { The course was organized to allow all students to } \\
\text { participate fully }\end{array}$ & Agreement \\
\hline
\end{tabular}

\section{Results}

To understand the validation of the STEM4S scope and STEM DDIF framework, we summarize the course achievement with the students' performance and the class evaluation by comparing it with other classes from NTNU. The graph compares the Innovation Design (I) in six bullet points: the first and second project scores, the student attendance, the report submission, the final grade, and the teacher's evaluation in the school system (Figure 7). The course achievement overall surpassed the average of other classes, showing how students spend their effort in this class and feel confident in their accomplishments. Finally, we conducted a quantitative analysis of the questionnaire to understand the detailed feedback of the course from the students. Table 4 shows the results of each question from the students (Table 4). To certify the liability of the data, we also calculated the standard deviation (SD) for each result.

The results show that less than half of the students knew about problem-based learning before the class, and this outcome explains that the PBL method is still not fully integrated into Taiwanese education. Another possibility is that students are not aware of the difference between PBL and other learning experiences. However, when we look at the course contribution section, it shows that most of the students acknowledged their improvement before and after the class (Q1 and Q2). In addition, the students self-evaluated improvement in their skill and knowledge and were aware of the contribution of completing the framework (Q3).

The impression of the problem-based learning experience indicates that some of the students found the assignment relatively challenging (Q5). However, while the students faced a challenging project, they observed improvements in their critical thinking and collaboration (Q6, Q8, and Q9). As the 21st Century Skills list critical thinking and collaboration as a set of discrete skills [36], the results reflect the suggested achievement of the STEM4S scope. Furthermore, the class established the students' confidence in facing the challenge and self-actualization of accomplishing the goal (Q7 and Q10). With these results, we note the effectiveness of STEM DDIF, a well-organized framework, in the design studio and how problem-based learning helps students develop their critical thinking in design education. 


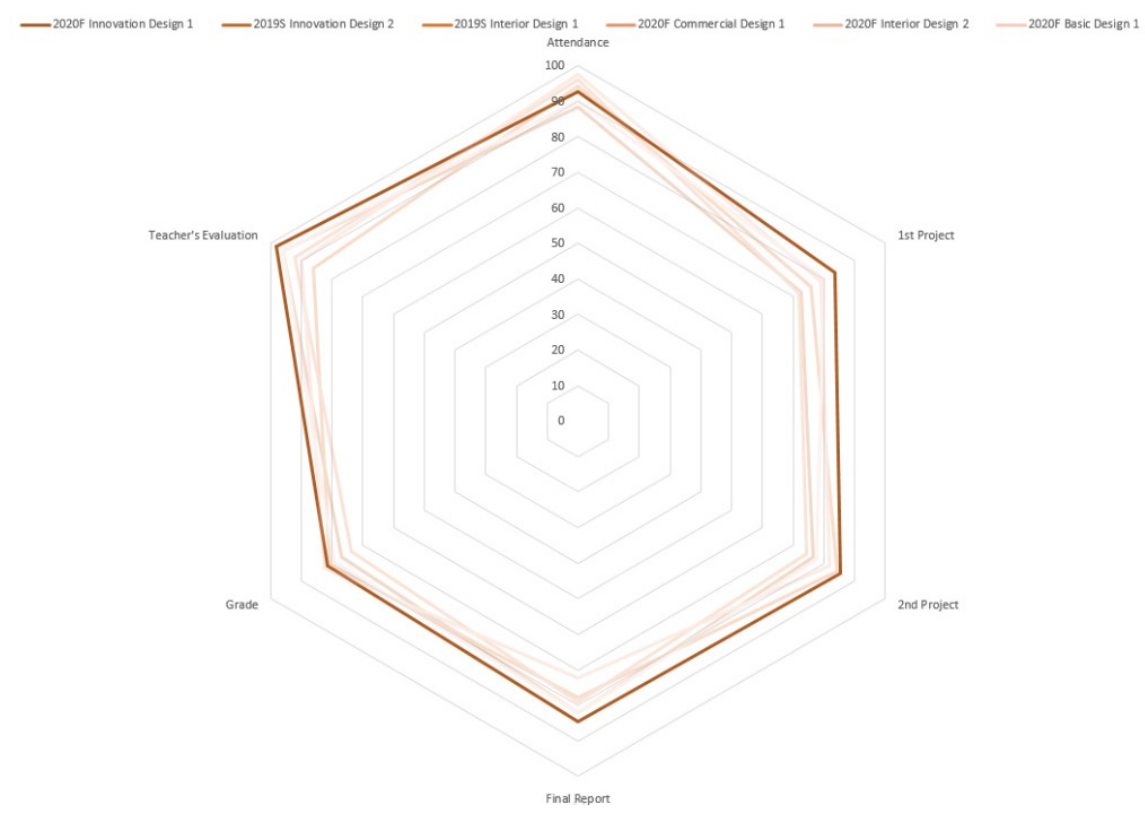

Figure 7. Comparison of six criteria of 2020F Innovation Design I with other NTNU design classes in the 2019 Spring semester-2020 Fall semester.

Table 4. Questionnaire results of problem-based learning and the course content (total of 19 answers).

\begin{tabular}{|c|c|c|c|c|c|c|c|}
\hline Question No. & Poor (1) & Fair (2) & Satisfactory (3) & Very Good (4) & Excellent (5) & Mean & SD \\
\hline Q1 & 1 & 7 & 10 & 1 & 0 & 2.58 & 0.67 \\
\hline Q2 & 0 & 1 & 4 & 10 & 4 & 3.89 & 0.79 \\
\hline Q3 & 0 & 2 & 9 & 4 & 4 & 3.53 & 0.94 \\
\hline \multirow{2}{*}{ Q4 } & 0 & 1 & 3 & 8 & 7 & 4.11 & 0.85 \\
\hline & Strongly disagree (1) & Disagree (2) & Neutral (3) & Agree (4) & Strongly agree (5) & & \\
\hline Q5 & 1 & 7 & 10 & 1 & 0 & 2.58 & 0.67 \\
\hline Q6 & 0 & 0 & 1 & 10 & 8 & 4.37 & 0.58 \\
\hline Q7 & 0 & 2 & 3 & 8 & 6 & 3.95 & 0.94 \\
\hline Q8 & 0 & 0 & 2 & 8 & 9 & 4.37 & 0.67 \\
\hline Q9 & 0 & 0 & 3 & 8 & 8 & 4.26 & 0.71 \\
\hline Q10 & 0 & 2 & 1 & 7 & 9 & 4.21 & 0.95 \\
\hline Q11 & 0 & 0 & 2 & 8 & 9 & 4.37 & 0.67 \\
\hline Q12 & 0 & 0 & 0 & 5 & 14 & 4.74 & 0.44 \\
\hline Q13 & 0 & 2 & 3 & 10 & 4 & 3.84 & 0.85 \\
\hline Q14 & 0 & 0 & 0 & 7 & 12 & 4.63 & 0.48 \\
\hline
\end{tabular}

In the last section, feedback on the class content, many students agreed with the clear objective of the class (Q11). The project topic's explicit goal was to help increase students' awareness of the problem and motivate them to create design solutions. The best feedback from the students was the agreement on the well-planned course content (Q12) and that the class allowed all students to participate fully (Q14). While some of the students felt the class content was relatively overloading for them (Q13), the framework of the class gained high participation from students.

Since the sample size of the study was small, we also took a look at the normality of the data. Figure $8 \mathrm{a}-\mathrm{c}$ shows the bar chart based on the questionnaire feedback from students. The chart in the skill-level questionnaire shows a relatively symmetrical distribution, while the charts of the problem-based learning and course contents show asymmetrical distributions. In Figure $8 b, c$, the medians of the chart are over 3 (neutral agreement), which describes that the majority of students agreed with the questionnaire contents, thus proving 
the effectiveness of STEM DDIF in the course. Thus, as the questionnaire summary, we can identify the effectiveness of STEM DDIF for developing students' critical thinking with the STEM4S scope of work. In the commenting section, some of the students pointed out that the guidelines helped them reduce their confusion at the beginning of the project, and they could feel confident about the outcome. Moreover, many of them mentioned teamwork as one of the most valuable experiences during the class.

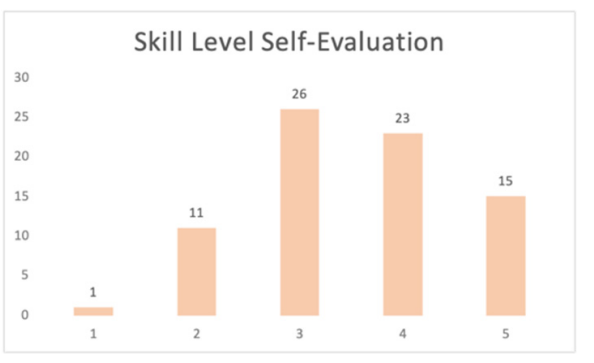

(a)

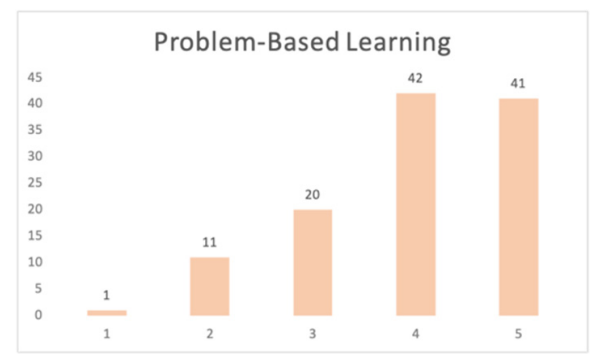

(b)

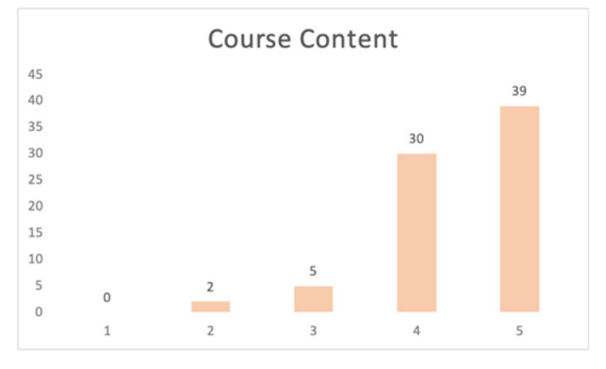

(c)

Figure 8. (a) Skill-level self-evaluation chart. (b) Problem-based learning chart. (c) Course content chart.

\section{Discussion}

This paper discussed how STEM education involves interdisciplinary education methods for training students in their skill set for the 21st century. Furthermore, implementing sustainability in education is another challenge we need to face in global and local institutions. Therefore, STEM4S opens a new opportunity for current pedagogy to incorporate multidisciplinary knowledge and strategies to face the bigger scale of challenges, such as the Sustainable Development Goals and climate change. SDG4 (Quality Education) is the priority strategy for achieving all the others and lies in an inclusive critical education [37]. As Chaleta et al. point out in their research, higher education plays an essential role in achieving SDG4. However, there is much work to be completed at the university level to promote the SDGs, and it will be necessary to involve the various sectors of the institution and the teachers for more collaborative and interdisciplinary work [15]. The role of education is to guarantee that students obtain the theoretical and practical knowledge for sustainable development by 2030 [38]. To carry out these tasks, students need to develop their design-thinking and problem-solving abilities. Thus, employing design in education provides an opportunity for students to work on real-world problem-solving skills. However, while STEM adopts design well, design education still needs to identify a framework for merging the studio system with the design-thinking process.

This paper explored the Framework for Innovation from the UK Design Council to set the precise design-studio framework for demonstration in the Department of Design at the National Taiwan Normal University. We provided the assignment, Design for Disaster, at Innovation Design (I), a studio-based design class, for students to follow the framework (STEM DDIF). Gyasi et al. mention that the main goals of STEM activities are achieved through frameworks, such as project-based, inquiry-based, and problembased learning. The more STEM activity designers integrate the disciplines, the more likely they will adopt different tasks and investigate learning outcomes [8]. Therefore, the Framework for Innovation investigation contributes to not just design education but other disciplines as well. The Design for Disaster project employed multidisciplinary input by guest lectures and consultant sessions to follow the scope of STEM4S. Complex sustainability-related challenges require future decision-makers to demonstrate and apply an interconnected and interdisciplinary understanding of sustainability [22]. Thus, higher education needs to educate students in basic theoretical and practical concepts to promote sustainable development and sustainable lifestyles [37]. Incorporating STEM DDIF aims to train students' sustainability competence. Based on Ferreras-Garcia et al., competence is the proven ability to use knowledge; skills; and personal, social, and methodological 
abilities in work or study situations and professional and personal development [39]. This research tried to promote students' design-thinking and problem-solving abilities in order to improve competence. To address design thinking and problem-solving, the students developed a design project with corrugated cardboard by articulating possible issues in disaster relief. Although some of the students found the assignment challenging, their work's outcome surpassed other classes' average grades and attendance rates. In addition, the questionnaire results showed how the students established their confidence in facing challenges and working within a team. Garcia-Gonzalez et al. describe that setting out on the path of sustainability requires a profound transformation in the way people think and act [38]. Therefore, students are the future agents of change for a sustainable world and addressing issues related to the SDGs. Moreover, educational methods of higher education need constant revisiting and evaluation to meet the criteria.

\section{Conclusions}

This study aimed to revisit STEM educational methods, such as design-based tasks, problem-based learning, and project-based learning, to investigate how students develop their cognitive skills in problem-solving and critical thinking. Furthermore, by understanding higher education's role in SDGs, specifically SDG 4, this study attempted to formulate the framework for STEM4S to elevate students' sustainability competence through design for disaster projects. Subsequently, the study's goal was to evaluate the framework's effectiveness by comparing the outcome of students at NTNU in the Department of Design. Finally, compared with the recent literature in STEM education for sustainability, this study discussed the validity of sustainability education's framework and future development in higher education.

The investigation pointed to the operational flow of design education in universities, mainly design-studio systems, with the difficulty of employing design thinking and lacking a framework for adopting the critical thinking process. Moreover, the study found that evaluation is one of the most critical phases of the design to manifest dynamic interaction between divergence and convergence. Subsequently, this study investigated how the Framework for Innovation could enhance students' design-thinking feedback loops in their design process. The questionnaire results and comparison with other classes suggest positive feedback of students' performance after employing framework to the Innovation Design (I) of the Department of Design, NTNU.

The limitation of this paper is that the participant sample was small. Therefore, the results could differ by increasing the number of participants, as well as the students' knowledge level. Moreover, the ideal condition for a STEM4S-adopted class is to have students of multidisciplinary educational backgrounds. However, in this research, most of the students were studying design, and actually, it is not simple to have multidisciplinary classes in the current university system. Therefore, further research of the STEM4S scope and framework needs to incorporate diverse participants and curricula to conduct students' learning experiences. A suggested, implementation is micro-teaching workshops with a multidisciplinary instructor and students to conduct STEM4S scope with STEM DDIF. We will conduct multiple workshops and collect different data to conduct qualitative and quantitative analyses in future research.

Sustainable development is a complex issue for a single discipline to face and find a solution. Education is the foundation of professional development and the next generation. Thus, it is necessary to develop forward-thinking education and train students for such challenges. STEM4S is still under development and needs urgent validating investigations to confirm the educational framework. This could be a platform for educators to debate education for the future generation.

Author Contributions: Conceptualization, M.-N.C. and D.N.; methodology, D.N.; software, M.-N.C.; validation, M.-N.C. and D.N.; formal analysis, D.N.; investigation, D.N.; resources, D.N.; data curation, M.-N.C.; writing—original draft preparation, D.N.; writing—review and editing, D.N.; 
visualization, D.N.; supervision, D.N.; project administration, D.N.; funding acquisition, D.N. All authors have read and agreed to the published version of the manuscript.

Funding: This research was conducted during the fall semester of 2020, supported by the Teaching Innovation and Professional Community project fund of the Center for Teaching and Learning Development, National Taiwan Normal University, Taiwan (Project Number: T10905180141).

Informed Consent Statement: Informed consent was obtained from all subjects involved in the study.

Acknowledgments: This article was subsidized by the National Taiwan Normal University (NTNU), Taiwan, ROC. The authors thank Shu-chang Kung (National Yang Ming Chiao Tung University), Chien-Kuo Teng (National Taiwan Normal University), and Masatoshi Tomita (National Taiwan University) for participating in the students' project review.

Conflicts of Interest: The authors declare no conflict of interest.

\section{References}

1. Martín-Páez, T.; Aguilera, D.; Perales-Palacios, F.J.; Vílchez-González, J.M. What are we talking about when we talk about STEM education? A review of literature. Sci. Educ. 2019, 103, 799-822. [CrossRef]

2. Manosuttirit, A. How to Apply Technology in STEM Education Activities. J. Phys. Conf. Ser. 2019, 1340, 012007. [CrossRef]

3. Mohr-Schroeder, M.J.; Cavalcanti, M.; Blyman, K. Stem Education: Understanding the Changing Landscape. In A Practice-Based Model of STEM Teaching: STEM Students on the Stage (SOS)TM; Brill Sense: Leiden, The Netherlands, 2015; pp. 3-14. [CrossRef]

4. Ritz, J.M.; Fan, S.-C. STEM and technology education: International state-of-the-art. Int. J. Technol. Des. Educ. 2015, 25, 429-451. [CrossRef]

5. United Nations. The 17 Goals. 2015. Available online: https://sdgs.un.org/goals (accessed on 29 November 2021).

6. Zamora-Polo, F.; Sánchez-Martín, J. Teaching for a Better World. Sustainability and Sustainable Development Goals in the Construction of a Change-Maker University. Sustainability 2019, 11, 4224. [CrossRef]

7. Filho, W.L.; Shiel, C.; Paço, A.; Mifsud, M.; Ávila, L.V.; Brandli, L.L.; Molthan-Hill, P.; Pace, P.; Azeiteiro, U.M.; Vargas, V.R.; et al. Sustainable Development Goals and sustainability teaching at universities: Falling behind or getting ahead of the pack? J. Clean. Prod. 2019, 232, 285-294. [CrossRef]

8. Gyasi, J.F.; Zheng, L.; Zhou, Y. Perusing the Past to Propel the Future: A Systematic Review of STEM Learning Activity Based on Activity Theory. Sustainability 2021, 13, 8828. [CrossRef]

9. Bascopé, M.; Reiss, K. Place-Based STEM Education for Sustainability: A Path towards Socioecological Resilience. Sustainability 2021, 13, 8414. [CrossRef]

10. Sayers, E.L.P.; Craig, C.A.; Skonicki, E.; Gahlon, G.; Gilbertz, S.; Feng, S. Evaluating STEM-Based Sustaina-bility Understanding: A Cognitive Mapping Approach. Sustainability 2021, 13, 8074. [CrossRef]

11. Park, W.; Wu, J.-Y.; Erduran, S. The Nature of STEM Disciplines in the Science Education Standards Docu-ments from the USA, Korea and Taiwan. Sci. Educ. 2020, 29, 899-927. [CrossRef]

12. Gao, Y. Centre for the Study of Higher Education (CSHE). In Report of Taiwan: STEM (Science, Technology, Engineering and Mathematics); Australian Council of Learned Academies: Melbourne, Australia, 2013. Available online: https://acola.org/stemcountry-comparisons-saf02/ (accessed on 29 November 2021).

13. Olsson, D.; Gericke, N.; Pauw, J.B.-D.; Berglund, T.; Chang, T. Green schools in Taiwan-Effects on student sustainability consciousness. Glob. Environ. Chang. 2019, 54, 184-194. [CrossRef]

14. Huang, Y.S.; Harvey, B.; Asghar, A. Bureaucratic exercise? Education for sustainable development in Taiwan through the stories of policy implementers. Environ. Educ. Res. 2021, 27, 1099-1114. [CrossRef]

15. Chaleta, E.; Saraiva, M.; Leal, F.; Fialho, I.; Borralho, A. Higher Education and Sustainable Development Goals (SDG)—Potential Contribution of the Undergraduate Courses of the School of Social Sciences of the University of Évora. Sustainability 2021, 13, 1828. [CrossRef]

16. Li, Y.; Schoenfeld, A.H.; Disessa, A.A.; Graesser, A.C.; Benson, L.C.; English, L.; Duschl, R.A. Design and Design Thinking in STEM Education. J. STEM Educ. Res. 2019, 2, 93-104. [CrossRef]

17. Oxman, R. Think-maps: Teaching design thinking in design education. Des. Stud. 2004, 25, 63-91. [CrossRef]

18. Exter, M.E.; Gray, C.; Fernandez, T.M. Conceptions of design by transdisciplinary educators: Disciplinary background and pedagogical engagement. Int. J. Technol. Des. Educ. 2019, 30, 777-798. [CrossRef]

19. Hathcock, S.J.; Dickerson, D.L.; Eckhoff, A.; Katsioloudis, P. Scaffolding for Creative Product Possibilities in a Design-Based STEM Activity. Res. Sci. Educ. 2014, 45, 727-748. [CrossRef]

20. Fortus, D.; Dershimer, R.C.; Krajcik, J.; Marx, R.W.; Mamlok-Naaman, R. Design-based science and student learning. J. Res. Sci. Teach. 2004, 41, 1081-1110. [CrossRef]

21. LaForce, M.; Noble, E.; Blackwell, C. Problem-Based Learning (PBL) and Student Interest in STEM Careers: The Roles of Motivation and Ability Beliefs. Educ. Sci. 2017, 7, 92. [CrossRef] 
22. Savery, J.R. Overview of Problem-Based Learning: Definitions and Distinctions. In Essential Readings in Problem-Based Learning: Exploring and Extending the Legacy of Howard S. Barrows; Purdue University Press: West Lafayette, IN, USA, 2015; Volume 9, pp. 5-15. Available online: https:/ / docs.lib.purdue.edu/cgi/viewcontent.cgi?article=1002\&context=ijpbl (accessed on 29 November 2021). [CrossRef]

23. Blumenfeld, P.C.; Soloway, E.; Marx, R.W.; Krajcik, J.S.; Guzdial, M.; Palincsar, A. Motivating Project-Based Learning: Sustaining the Doing, Supporting the Learning. Educ. Psychol. 1991, 26, 369-398.

24. Bequette, J.W.; Bequette, M.B. A Place for Art and Design Education in the STEM Conversation. Art Educ. 2012, 65, 40-47. [CrossRef]

25. Zande, R.V. Teaching Design Education for Cultural, Pedagogical, and Economic Aims. Stud. Art Educ. 2010, 51, 248-261. [CrossRef]

26. Long, J.G. State of the Studio: Revisiting the Potential of Studio Pedagogy in U.S.-Based Planning Programs. J. Plan. Educ. Res. 2012, 32, 431-448. [CrossRef]

27. Wang, T. A New Paradigm for Design Studio Education. Int. J. Art Des. Educ. 2010, 29, 173-183. [CrossRef]

28. Bashier, F. Reflections on architectural design education: The return of rationalism in the studio. Front. Arch. Res. 2014, 3, 424-430. [CrossRef]

29. El-Latif, M.A.; Al-Hagla, K.S.; Hasan, A. Overview on the criticism process in architecture pedagogy. Alex. Eng. J. 2020, 59, 753-762. [CrossRef]

30. Chiaradia, A.J.; Sieh, L.; Plimmer, F. Values in urban design: A design studio teaching approach. Des. Stud. 2017, 49, 66-100. [CrossRef]

31. Dym, C.L.; Agogino, A.M.; Eris, O.; Frey, D.D.; Leifer, L.J. Engineering Design Thinking, Teaching, and Learning. J. Eng. Educ. 2005, 94, 103-120. [CrossRef]

32. Kremer, G.; Mohammed, S. Facilitating Design Learning in a Cooperative Environment: Findings on Team Functioning. Int. J. Eng. Educ. 2006, 22, 10.

33. Banathy, B.H. Designing Social Systems in a Changing World; Springer: Singapore, 2013.

34. Council, D. Design for Innovation; Retrieved April; Design Council: London, UK, 2011; Volume 27, p. 2012.

35. R.O.C. (Taiwan) Envrionmental Protection Administration Executive Yuan. Recycling Management in Taiwan. 2020. Available online: https: / / www.epa.gov.tw / eng/F7AB26007B8FE8DF/b657a5e9-20e8-40bc-9358-58a9b08de2f8 (accessed on 30 November 2021).

36. Bellanca, J.A. 21st Century Skills: Rethinking How Students Learn; Solution Tree Press: Bloomington, IN, USA, 2010.

37. Prieto-Jiménez, E.; López-Catalán, L.; López-Catalán, B.; Domínguez-Fernández, G. Sustainable Development Goals and Education: A Bibliometric Mapping Analysis. Sustainability 2021, 13, 2126. [CrossRef]

38. García-González, E.; Jiménez-Fontana, R.; Azcárate, P. Education for Sustainability and the Sustainable Devel-opment Goals: Pre-Service Teachers' Perceptions and Knowledge. Sustainability 2020, 12, 7741. [CrossRef]

39. Ferreras-Garcia, R.; Sales-Zaguirre, J.; Serradell-López, E. Sustainable Innovation in Higher Education: The Im-pact of Gender on Innovation Competences. Sustainability 2021, 13, 5004. [CrossRef] 